\title{
A Comparative Analysis of Gender Effectiveness in Public and Private Secondary Schools Teachers' in Oredo Local Government of Edo State Nigeria
}

\author{
Mercy O. Omobude \\ Faculty of Education, University Of Benin \\ Benin City, Nigeria \\ Ujiro Igbudu \\ Faculty of Education, University Of Benin \\ Benin City, Nigeria \\ Tel: 234-803-359-32-93 E-mail: director@nosakhare.com
}

$\begin{array}{lrr}\text { Received: March 20, } 2012 & \text { Accepted: May 10, } 2012 & \text { Published: June 1, } 2012 \\ \text { doi:10.5539/res.v4n2p175 } & \text { URL: http://dx.doi.org/10.5539/res.v4n2p175 }\end{array}$

\begin{abstract}
The study was undertaken to compare teacher's level of effectiveness in public and private secondary schools in Oredo Local Government Area of Edo State. Two hypotheses were formulated for the study and the reviewed literature covered all the variables of interest. The study was hinged on the ex-post- facto research design. A special instrument known at the Teachers Gender Performance Evaluation Report Card (TGPERC) was developed to generate the needed data. Schools from where the teachers were selected were chosen via convenience sampling techniques. The data collected were analyzed using the t-test statistics for independent sample and all hypotheses tested at 0.05 level of significance. The result of the analysis revealed that the public and private school teachers have different levels of effectiveness in Oredo Local Government Area of Edo State. Nigeria.
\end{abstract}

Keywords: Comparative analysis, Gender effectiveness, Public and private schools

\section{Introduction}

In the past, education was seen as an instrument used to sharpen man's character or personal being. Man was seen as a being that has the ability to learn, develop skill and improve living. This early system of education does not demand or reflect economic problems or planning issue (Hurd, 1969; Obi, 1977; Burkhead \& Miller, 1971). The instruments needed to effect the ability of learning were not readily available and if at all, were not systematically used to meet its aims. This misappropriation made the meaning of education to be underrated in most Sub-Saharan African Countries, Nigeria inclusive.

Education is also said to be a tool for national development and seen to be the biggest industry in Nigeria. The informal system of education in Nigeria was practiced by every home, fairly old individuals and this method is simply learning by copying or initiating, and in this, we have the apprenticeship system where people could be attached to specialize on their own. For instance, a carpenter training another person to be a specialist. Though this method was effective the country grew to a stage to have need for the formal system of education. In this system, manpower was recruited and with the help of other educational materials, teaching and learning became more effective. This system first started in the $11^{\text {th }}$ century in the East by Islamic scholars and the aim was to propagate Islam and teach Arabic (Mannheim \& Steward, 1962). Whatever type of education it was men were mainly involve. While the women were restricted to the training of their mothers in the kitchen and domestic chores and the aim was to make them become good housewives when they are married. They hardly had the opportunity to be formally educated. 
According to Imogie (2007) Women have traditionally been seen as home makers and character makers. In the same, Betitu (2002) observed that countries that have raised the status of their women educationally, socially, politically and economically generally enjoy a high standard of living.

Nevertheless, the importance of education cannot be overemphasized as it is perceived to be the missing link in the process of national development and social justices. Now in Nigeria, it is believed that the standard of Education has fallen compared to what it was before now (Soyibo, 1986; Ajimoko, 1976). This however has been linked with failure of government to provide enough funds for education, population explosion, inadequate performance of teachers as there are no job satisfaction or incentives and this result to job inconsistence. These lapses had led to inadequate performance of students in schools and thereby reducing the quality of education.

It is obvious that the standard of education has fallen beyond reasonable doubts right from primary through territory levels. For this, the purpose for education has been defeated. According to Nwandani (1993) andArubayi (1998), education has been seen and described as an investment in frustration. Education is said to be a major employer of highly skilled personnel and money with which education acquires its human and physical input.

The prevailing economic condition in Nigeria has some adverse effects on workers (teachers) and has resulted to unfavourable consequences on teachers and students thereby affecting their performances. These consequences had resulted to teachers' ineffectiveness and inefficiency. This condition has also caused serious damages to educational wastage: high failure rate of inefficiency and incapable manpower as a result of poor training processes by teachers who lacks adequate and sufficient materials motivation and job satisfaction of instruction in other various fields of endeavour is paramount to other roles as far as teaching, learning is concerned. These roles are of great concern to students, parents and school authorities. It is important is that the teacher knows what to teach, and how to teach it and then teach effectively. Some teachers are not efficient in the use of actual teaching method as well as in their use to teaching materials. It should be noted that the teachers effectiveness whether is of male or female foremost concern in teaching learning process. Since students are the consumers, their perception is the best measure of teacher's effectiveness. Therefore, the present study sought to obtain empirical evidence of teachers' effectiveness and proposed ways to enhance their effectiveness.

\section{Statement of the problem}

It is been alleged that public secondary teachers do not do their jobs well. Students taught by them perform very poorly in standardized examinations either because they are not taught well or not taught at all. Teachers are observed loafing or trading while they are supposed to be teaching.

\section{Materials and Methods}

\subsection{Research design}

The ex-post-facto research design was adopted for the study principally because of the data that have already occurred. Another reason why the design was adopted was because the variables of study were not manipulated.

\subsection{Sampling and sampling technique}

The sample was made up of 39 male and 61 female totally 100 public male and female school teachers with 57 male and 44 female private school teachers, totally 101 teachers. Convenience sampling technique was adopted to select the schools from which the teachers were chosen. The first 100 male and female teachers in the different public in the Oredo LGA schools were used as subjects for the study. While the first 101 male and female teacher in different private schools in Oredo Local Government Area were also selected and used as subjects for this study.

\subsection{Instrumentation}

A special instrument known as Teachers' Gender Performance Evaluation Report Card (TGPERC) was developed to generate the needed data for the study. Part "A" of the instrument provided background information on the independent variables while part "B" contained items that measured the level of effectiveness of male and female teachers. In both private and public schools selected in Oredo Local Government Area of Edo State.

\subsection{Administration of instrument}

The instrument was administered personally by the researchers with the help of the school principals to supply the needed statistics for the study analysis. The completed instruments were collected from the principals immediately after completion. Some that were not properly completed were rejected. 


\section{Data Analysis}

The t-test statistics for independent samples was used to test the hypotheses raised. The statistics was employed because of the interval nature of the generated scores and the sample that was relatively large.

$\mathrm{Ho}_{1}$ : There is no significant difference in effectiveness between public and private school male teachers.

$\mathrm{Ho}_{2}$ : There is no significant difference in effectiveness between public and private school female teachers.

\section{Results}

The results for the study are presented in table 1-2.

\subsection{Hypothesis One}

$\mathrm{Ho}_{1}$ : There is no significant difference in effectiveness between public and private school male teachers.

To test this hypothesis, the scores obtained from both schools were analyses using t-test for two independent samples. The summary of the analysis is presented in table 1:

The analysis of the data in table 1 revealed that the calculated value of 2.33 is higher than the critical value of 1.96 at 0.05 level of significant. This showed that there is a significant difference in gender effectiveness between public male and private male teachers.

\subsection{Hypothesis Two}

$\mathrm{HO}_{2}$ : There is no significant difference in effectiveness between public and private school female teachers.

To test these hypotheses, the t-test for independent sample was employed to analyze the scores from the schools. The summary of the analysis is presented in table 2

Table2 showed that the calculated value of 2.90 is higher than the critical value of 1.96 at 0.05 level of significance. This showed that public and private school female teacher do not have the same level of effectiveness.

\section{Discussion of Findings}

The finding of no difference in gender effectiveness between public and private secondary schools teachers are not surprising. This could be as a result of the same training both categories of teachers are exposed to. However, differences in the levels of motivation and supervision shows that private schools male and female teachers are more effective than public male and female school teacher. In private schools, teachers are carefully supervised to ensure that they do just what they are employed to do. Similarly, Salaries are relatively paid as and when due to motivate them to do their work as expected. Therefore, the obtained higher mean scores for all categories of private school teachers suggest that private schools are more effective. In contemporary times in Nigeria, social services management especially education by government have come under very serious condemnation. Despite the huge investment in education, it seems that nothing is actually happening in the school systems. Public schools are not able to graduate students within specified normal time. Even when students are not able to defend their certificates. They are merely certificated without actually acquiring useable skills. This trend agrees with the views of Berkowitz (1980) that public school teachers whether male or female are less effective than private school male and female secondary school teachers because of poor supervision of assigned tasks by management. This could be true because of the perceived high level of supervision in private schools. Private schools management ensures that every teacher works very hard even more for his/her remuneration.

It is an obvious fact that most qualified teachers in Nigeria. Today prefer to work in private schools were better salaries are paid. Chase (1950) and Arubayi (1987) had earlier supported in their claim that private school management have better conditions of service that attract better qualified teachers. According to Gudrigge (1980) great teachers are always attracted to teach in private schools. The alleged teachers attrition rate from public to private schools therefore could be as a result of the claim that private schools attract better qualified and experienced teachers with good salaries. This is unlike in public schools where many lazy teachers capitalize on salaries that are not paid regularly to slack in performing assigned duties. These teachers play their time away and actually do not teach what they have been employed to teach. At the end, many student fail examinations. Even when they pass examination, they are not able to acquire competency in the skills and knowledge taught. The issues of performance or effectiveness has nothing to do with sex, whether male or female a teacher would do well if in the right environment, supervised and motivated. According to Imogie and Ereikhuemen (2008) Gender is a social contract connotes the differentiated roles and responsibilities of men and women in a particular society. It is therefore described that males and females have equal access to education and all fields of 
study to check gender imbalance and afford both sexes equal opportunities to contribute to and benefit from the social cultural, political and economic development of the nation.

\section{Conclusion}

The conclusion of this study is that private schoolteachers are more effective in their jobs than their counterparts in the public schools.

\section{Recommendations}

Based on the findings of this study, the following recommendations were made:

i. Government should pay public school teachers regularly to motivate them to work harder to justify the huge investment into the education sector.

ii. Public school teachers should be sent periodically on in-service training to guarantee better job performance.

iii. Government should provide better conditions of service for public school teacher to provide better conditions of service for public school teacher to prevent/control the increasing rate of teacher attrition.

iv. Public school teacher should earn all their entitlement while in service instead of saving some for retirement as is done in private sector.

\section{References}

Ajimoko, I. O. (1976). Quantity and quality in Nigeria primary education: Prospective in the U.P.E Programme. West African Journal of Education, 20(2), 94-103.

Arubayi, E. (1988). Observed and expected standards of education in Nigeria, A case study of Bendel State, Benin City. Faculty of education, University of Benin.

Burkhead, J., \& Miller, J. (1971). Public expenditure. London: MacMillian.

Hurd, P. D. (1969). The Laboratory in science instruction, New Directions in teaching school science. Chicago: Randy McNally and Co.

Imogie, A., \& Eraikhuemen, L. (2008). An inquiry into sex differentiation in admission and academic performance at the university of Benin. Nigeria Benin Journal of Gender Studies.

Mannheim, K., \& Steward, W. A. C. (1962). An introduction of education. New York: Routledge and Kegan Paul. The Humanities Press.

Obi, S. D. (1977). A Manual for school libraries on small budget. Ibadan: Oxford University Press.

Soyibo, K. O. (1986). A critical review of some of the causes of student poor Performance in Science. Journal of Science Teachers Association of Nigeria. Annual Conference Proceeding.

Table 1. Summary of analysis for difference in effectiveness between public and private school male teachers

\begin{tabular}{lccccc}
\hline Variables of interest & $\mathrm{N}$ & $\mathrm{X}$ & $\mathrm{df}$ & Cal-t & Crit-t \\
\hline Public MaleTeachers & 39 & 58.44 & & & \\
Private Male Teachers & 57 & 71.80 & 94 & 2.33 & 1.96 \\
\hline $\mathrm{P}<0.05$ & & &
\end{tabular}

$\mathrm{P}<0.05$

Table 2. Summary of analysis for difference in effectiveness between public and private school female teachers

\begin{tabular}{lccccc}
\hline Variables of Interest & $\mathrm{N}$ & $\mathrm{X}$ & $\mathrm{df}$ & Cal-t & Crit-t \\
\hline Public Female Teachers & 61 & 55.20 & & & \\
Private Female Teachers & 44 & 61.72 & 105 & 2.90 & 1.96 \\
\hline
\end{tabular}

$\mathrm{P}<0.05$ 